\title{
On the Issue of the Need to Adopt a Strategy for Legal Education and Upbringing of Youth in the Russian Federation
}

\author{
Ekaterina Shadrina ${ }^{1},{ }^{*}$ Veronika Abakanova ${ }^{1}$, Asel Rashidova $^{1}$, Kamila Omarova $^{2}$ \\ ${ }^{1}$ Herzen State Pedagogical University of Russia, Russia \\ ${ }^{2}$ Daghestan State University, Russia \\ *Email: ksahdrina@yandex.ru
}

\begin{abstract}
At present, in Russia, the younger generation's legal upbringing is one of the priority areas of modernising state educational policy. It is based on a system of knowledge and understanding of the law and actions aimed at their practical implementation, which is directly related to the state of education and upbringing in society. The main issue in the modernisation of education should be the expansion and deepening of the legal knowledge of students and the cultivation of legal behavior, the development of strong legal traditions, and the direct overcoming of legal nihilism. This study aims to develop a mechanism that can increase the level of legal awareness among young people and overcome legal nihilism. Based on the theoretical analysis of scientific literature, the system of normative legal acts, the results of a sociological survey, authors concluded that in achieving the designated goal, the educational environment occupies a fundamental but not an exhaustive place, and the globality of the considered problem necessitates the involvement of all mechanisms of the state in its resolution and civil society. These circumstances require adopting the Strategy of Legal Education and Upbringing of Youth as a document of strategic planning at the federal level.
\end{abstract}

Keywords: Upbringing, Public policy, Education, Law, Legal behavior.

\section{INTRODUCTION}

In recent years, qualitative changes have been taking place in Russia's higher education system - a new education system is being established. This, in particular, is stated in the Federal Target Program for the Development of Education for 2016-2020. This program enshrines the implementation of the transition "from the system of mass education, characteristic of the industrial economy, to continuous individualised education for all, the development of education associated with the world and domestic fundamental science, focused on the formation of a creative socially responsible personality" [1].

One of the critical points in the reorganisation of the modern domestic education system is to change the view on the formation of the student's personality. This is confirmed by the normative acts in the field of education, adopted in the last decade. Thus, according to the
Fundamentals of the State Policy of the Russian Federation in the Development of Legal Literacy and Legal Awareness of Citizens (hereinafter - the Fundamentals), approved in April 2011, the state policy in the field of education in our country is aimed at creating a positive legal consciousness, a high level of legal culture of the population, traditions of unconditional respect to the law, law and order and court, honesty and conscientiousness as the predominant model of social behavior, as well as to overcome legal nihilism in society, which hinders the development of Russia as a modern civilised state. Among the measures of state policy in the field of education, the Fundamentals provide for such as the development of the practice of teaching the basics of law in educational institutions of various types and types, support for various options for regional models of legal education, the development of training courses, including legal topics, appropriate educational programs, teaching and methodological aids [2]. 
It should be noted that the particular importance of legal education, legal upbringing, and legal consciousness formation is also drawn attention in the scientific community. As V.V. Neklyudova "The solution of legal upbringing issues is possible with the joint actions of representatives of jurisprudence, pedagogy, psychology and other related sciences" [3, p.186]. Thus, some scholars consider legal education problems in connection with legal upbringing [4,5]; others complement the third elements - legal awareness $[6,7,8]$.

\section{MATERIALS AND METHODS}

To achieve this goal, a theoretical analysis of scientific literature (Russian and foreign) was carried out on the problems of legal education, upbringing, the formation of legal consciousness; the main regulatory legal acts of the Russian Federation that regulate the studied issues were analysed; practical pedagogical experience and sociological survey data were generalised. Processes of education and upbringing in the field of education and upbringing. The methodological basis of the research was formed by general scientific methods of cognition and specific scientific methods: the comparative legal method, the method of legal modelling and the method of document analysis.

\section{RESEARCH}

One of the main principles of state policy and legal regulation of relations in the field of education, the Federal Law "On Education in the Russian Federation" calls, in particular, the humanistic nature of education, the priority of free personal development, the upbringing of mutual respect, industriousness, citizenship, patriotism, responsibility, legal culture [9].

In the same vein, the main provisions of the education development Strategy in the Russian Federation for the period up to 2025 (hereinafter referred to as the Strategy) should be considered. According to the Strategy, the priority task for Russia in the field of raising children is the development of a highly moral person who shares Russian traditional spiritual values, who has relevant knowledge and skills, can realise his potential in modern society, ready for the peaceful creation and protection of the Motherland. The document under consideration does not highlight a separate direction of upbringing - legal. Based on the essence and content of civic upbringing, which, according to G.V. Buyanova, involves "the formation of a stable system of moral and semantic attitudes of the individual, to resist the ideology of extremism, nationalism, xenophobia, corruption, discrimination on any grounds" $[4, \mathrm{p} .42]$, it is undoubtedly related to the legal sphere and presupposes knowledge of the legal properties of the listed categories. Scientists-educators who study the main directions of educational activities at the university, among others, unanimously name civil upbringing [10, p.729].

When it comes to legal education and upbringing, attention is drawn to the danger of the development of legal nihilism, which leads to the devaluation of genuine spiritual and moral values, serves as the basis for many negative social phenomena, including drunkenness, drug addiction, pornography, prostitution, family violence, domestic crime, disregard for the rights and interests of others protected by law, encroachment on someone else's property, arbitrariness, lynching. A.A. Merkelov, N.V. Danichev note: "Legal nihilism, the growth of crime, the moral and legal degradation of youth, etc. have a destructive effect on the system of internalisation of universal human values" [5, p.148]. O. A. Andrienko, T.A. Bezenkova, in conjunction with this negative phenomenon, indicate infantilism, a demonstrative avoidance of necessary life tasks by young people [11, p.30].

It seems that the fundamental reason for legal nihilism lies in society's low legal culture, in general, and of its members, in particular. This is especially true of the young generation of citizens of our country, including student youth. Objective factors can explain the exposure of young people to legal nihilism. The formation of legal consciousness characterises the younger generation. At the same time, there is a lack of life experience and a lack of a sufficient volume of legal knowledge. Suppose life experience comes over time and it is rather difficult to influence its existence. In that case, the main task is to increase the volume of legal knowledge, the need for legal upbringing. In this field of activity, educational institutions are assigned a central role. R.R. Muslumov, A.S. Menshikov noted that the legal consciousness of an individual affects all aspects of life. Therefore, special attention is required to create psychological and pedagogical conditions that contribute to young people's development $[6, p .48,8$, p.50]. It becomes essential to lay the foundations of legal consciousness, respect for the law, compliance with legal norms in adolescence when a person's personality is formed. The main factors that make it possible to form legal consciousness among student youth are, in our opinion, legal education and the availability of a sufficient amount of legal knowledge obtained, including as a result of legal education $[12$, p.66]. At the same time, their harmonious combination becomes significant. As noted in the scientific literature, in the learning process, a student must develop the main quality - the willingness to learn throughout his life, which can be achieved only in integrating training and education $[13,14]$.

Legal educational disciplines aimed at the formation of legal knowledge used in the framework of legal upbringing and the formation of legal consciousness, as a rule, are included in the approved standards of higher professional education in various specialities. Of course, 
modern society, with its political and socio-economic processes, the expansion of international cooperation necessitates the possession of legal competence for any specialist.

Attention is drawn to this fact in the foreign scientific literature. I. O. Varakuta notes that legal education is a necessary element of personal access to law, which forms the attitude to law, trains a socially active member of society who knows his rights and opportunities, can defend and protect them in all ways [15]. According to V. Jonynienè, L. Petrauskienè, It shapes the formation of students' competences so that students are enabled in their everyday life to follow the law, morality, and other social rules determined by internalised legal culture and consciousness [16, p.93].

However, the question arises, on the one hand, of the adequacy of the legal knowledge amount provided in this case. On the other hand, the demand for legal knowledge on the part of students of non-legal universities and the possession of the competencies provided. Suppose the volume of legal knowledge and the significance of the proposed knowledge are insufficient. In that case, it is unnecessary to talk about the formation of legal culture and legal consciousness as the results of the implementation of "law-upbringing" and "laweducation" among students. Therefore, to achieve legal education goals, legal upbringing and the required level of legal awareness in their unity, an integrated approach is needed. S.V. Rybak notes: "The priorities of the Russian legal policy are, first of all, the guidelines of its activity that are relevant for the state, which, based on the current realities, should be aimed at the formation of spirituality, a high level of legal awareness and legal culture in Russian society. the opportunity and will contribute to the preservation of the primordially Russian spiritual, moral and cultural traditions, which, in turn, will have a favourable effect on the sphere of ensuring the rights and freedoms of man and citizen, the lawupbringing process should be maximally adapted to Russian realities" [17, p.303].

A sociological survey was conducted to identify the level of legal knowledge, legal culture and legal awareness, and factors affecting their formation, among students of non-legal specialities of the Herzen State Pedagogical University of Russia in December 2020. Questionnaires were developed, based on which a survey of 60 respondents (students of economic and historical specialities) was conducted. The questionnaires consisted of several blocks, which reflected the following questions: general information about the respondent (gender, course, speciality); knowledge of the leading legal acts related to human rights; sources of obtaining legal information; attitude to the law as the primary regulator of legal relations; a proposal to choose the most effective forms of dissemination of legal knowledge.

The study revealed the following features of the formation of legal consciousness in students. The level of legal knowledge regarding the main normative legal acts related to human rights is high: $85 \%$ indicated knowledge of the Russian Federation's Constitution, the Convention on the Rights of the Child, the European Convention for the Protection of Human Rights and Fundamental Freedoms. $78 \%$ of respondents consider the law a necessary regulator of public relations; $22 \%$ - expressed a negative attitude towards law and the justice system. They see the achievement of their goals through the use, including illegal methods. The primary source of information for students' legal nature was the mass media $(55 \%)$, followed by the university and teachers $(38 \%)$, other sources - 7\% (table 1.).

\section{CONCLUSION}

The modern regulatory legal field analysis indicates that special attention is paid to the issues of legal education and legal upbringing at the level of lawmaking. However, despite the state's attempts to assign the task to educational organisations through the mechanisms of legal education and upbringing to raise the level of legal awareness of young people and, as a result, eradicate (or minimise) legal nihilism, it remained unresolved. The educational sphere is fundamental, but not sufficient to achieve the goals of legal education and upbringing. There is a need to involve in this process all institutions of the state and civil society.

Table 1. Research of the level of legal knowledge, legal culture and legal awareness among students of non-legal specialities

\begin{tabular}{|l|l|}
\hline \multicolumn{1}{|c|}{ Compared indicators } & \multicolumn{1}{|c|}{ Answer results } \\
\hline $\begin{array}{l}\text { Level of legal knowledge regarding } \\
\text { the main normative legal acts related } \\
\text { to human rights }\end{array}$ & $\begin{array}{l}85 \% \text { named the Constitution of the Russian Federation, the } \\
\text { Convention on the Rights of the Child, the European Convention for } \\
\text { the Protection of Human Rights and Fundamental Freedoms } \\
15 \% \text { found it difficult to answer }\end{array}$ \\
\hline $\begin{array}{l}\text { Attitude to the law as a necessary } \\
\text { regulator of social relations }\end{array}$ & $\begin{array}{l}78 \% \text { agreed; 22\% expressed a negative attitude towards law and the } \\
\text { justice system, and they see the achievement of their goals through the } \\
\text { use, including illegal methods }\end{array}$ \\
\hline $\begin{array}{l}\text { The primary source of information of } \\
\text { a legal nature }\end{array}$ & \begin{tabular}{l} 
Mass media - 55\%, university and teachers - 38\%, other sources - 7\%. \\
\hline
\end{tabular}
\end{tabular}


This problem's global nature forces us to speak about developing a Strategy for young people's legal education and upbringing. Since depending on the stage of socialisation, the individual receives legal knowledge in the family, educational organisations, the media, government agencies, public organisations, all institutions of the state and civil society should be included in the Strategy as subjects. Taking into account the conducted research, we see the following as the main tasks of the Strategy implementation: changing the view on the formation of the student's personality; increasing the role of educational institutions in the process of forming the legal consciousness of young people, including ensuring the possession of legal competence by any specialist; development of institutions of legal education and legal upbringing of students, starting from the preschool stage.

\section{REFERENCES}

[1] Decree of the Government of the Russian Federation of December 26, 2017, N 1642 (as amended of August 11, 2020) "On approval of the state program of the Russian Federation Development of education", Collected Legislation of the Russian Federation, Iss. 1 (Part II), Art. 375, 2018.

[2] Fundamentals of the Russian Federation's state policy in the development of legal literacy and legal awareness of citizens (approved by the President of the Russian Federation on 28.04.2011 N Pr-1168), Rossiyskaya Gazeta, Iss. 151, July 142011.

[3] V.V. Neklyudova, Actual problems of legal education of modern student youth. Problems of modern teacher education 58-2 (2018) 185 - 188.

[4] G.V. Buyanova, The main yields of educational activity in the system of modern higher education. Perspectives of Science and Education 37(1) (2019) 37-50. DOI: https://doi.org/10.32744/pse.2019.1.3 (In Russ., abstr. in Engl.).

[5] A.A. Merkelov, N.V. Danichev, Legal training and legal education of cadets are factors in forming legal culture, Directions and prospects for the development of education in the Russian Federation's military institutes: Collection of scientific articles of the IX Interuniversity scientificpractical conference with international participation, In 3 parts. Under the general editorship of S.A. Kutsenko, 2018, pp. 147-152, Novosibirsk Military Institute named after General of the Army I.K. Yakovlev of the National Guard of the Russian Federation, Novosibirsk.

[6] R.R. Muslumov, Issues of formation of legal consciousness of personality, Perspectives of
Science and Education 42(6) (2019) 44-54. DOI: https://doi.org/10.32744/pse.2019.6.4

[7] M.L. Boittin, New perspectives from the oldest profession: abuse and the legal consciousness of sex workers in China. Law Soc. Rev. 47(2) (2013) 245 278. DOI: https://doi.org/10.1111/lasr.12016

[8] A.S. Menshikov, Anthropology without Ethnography: M. Scheler's Philosophy of War and the Search for the "Nature of Man", Ethnographic Review 5 (2018) 43-58. DOI: https://doi.org/10.31857/S086954150001476-3

[9] Federal Law of December 29, 2012, N 273-FZ (as amended on July 31, 2020) "On Education in the Russian Federation" (as amended and supplemented, entered into force on September 1, 2020), Collected Legislation of the Russian Federation, Iss. 53 (Part 1), Art. 7598, 2012.

[10] Sh.Kh. Kenzhaev, F.E. Bokiev, G.A. Amanov, The organisation of educational activities at the university, Young scientist 5 (2013) 728-731.

[11] O. Andrienko, T. Bezenkova, From the experience of the organisation of educational activities with students of adolescence. Perspectives of science and education 5(35) (2018) 26-32. DOI: https://doi.org/10.32744/pse.2018.5.3 (in Russian).

[12] E.A. Sokolova, Legal consciousness as a result of legal education and the basis for forming the electoral activity of schoolchildren. Humanitarian treatise 21 (2018) 66-68.

[13] Jim-Olav Fors. Development of professional commitment among students in social work education. Social Work Education 36:5 (2017) 529541.

[14] Patricia Champy-Remoussenard, «Les transformations des relations entre travail, éducation et formation dans l'organisation sociale contemporaine: questions posées par trois dispositifs analyseurs», Revue française de pédagogie [En ligne], 190 | janvier-février-mars 2015, mis en ligne le 31 mars 2018, consulté le 25 octobre 2018. Retrieved from: http://journals.openedition.org/rfp/4675 DOI: https://doi.org/10.4000/rfp.4675

[15] I.O. Varakuta, Legal consciousness, legal upbringing and legal education: the paradigm of interdependence. Retrieved from: https://www.researchgate.net/publication/3435224 47 Legal consciousness legal upbringing and le gal education the paradigm of interdependence, 2020 DOI: https://doi.org/10.33663/2524-017X2020-11-16 
[16] Ž.V. Jonyniené, L. Petrauskienè. The Role of Legal Education in Development of Students Personal Competencies: Conceptions of 10-12 Grade Students and School Staff, Socialinis darbas 12(1) (2013) 93-108.

[17] S.V. Rybak, The role of legal culture and legal education in the mechanism of ensuring human rights and freedoms. Business Education. Right 2(43) (2018) 301-303. 